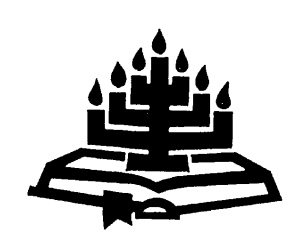

\title{
Can we use the New Testament in the way which the New Testament a uthors use the Old Testament? 1]
}

Steve Moyise

Bishop Otter Centre for Theology and Ministry

University College

Chichester

ENGLAND

E-mail: s.moyise@ucc.ac.uk

\section{Abstract}

Can we use the New Testament in the way which the New Testament authors use the Old Testament?

Ever since the discovery of the Dead Sea Scrolls, scholars have drawn parallels between the way the New Testament authors used the Scriptures and the use of Scripture found in the Qumran writings. This method has raised difficult questions, because some of the exegetical methods, such as allegory, word-splitting and the use of variant texts, are generally regarded as erroneous today. However, other scholars have contended that this comparative approach does not do justice to New Testament exegesis and have argued that the New Testament authors developed a distinctive messianic, ecclesiocentric or trinitarian form of exegesis. This view sheds new light on the old question of whether the Church can use the New Testament in the same way that the New Testament authors use the Old Testament.

\section{Opsomming}

Kan ons die Nuwe Testament op dieselfde wyse gebruik word as wat die Nuwe-Testamentiese skrywers die Ou Testa ment gebruik het?

Sedert die ontdekking van die Dooieseerolle het wetenskaplikes parallelle getrek tussen die wyse waarop die skrywers van die Nuwe Testament die Skrifte gebruik het en die gebruik van die Skrif soos dit voorkom in die

1 A revised version of a paper delivered at a meeting of the Gereformeerde Teologiese Vereniging of Potchefstroom - 15 April 2002. 
Qumram-geskrifte. Hierdie metode het moeilike vrae laat ontstaan omdat sommige eksegetiese metodes soos byvoorbeeld die gebruik van allegorie, woordeksegese en die gebruik van teksvariante vandag algemeen as foutief beskou word. Ander navorsers voer egter aan dat hierdie vergelykende metode nie laat reg geskied aan Nuwe-Testamentiese eksegese nie en argumenteer dat die skrywers van die NuweTestament 'n onderskeidende messiaanse, kerksentriese of trinitariese vorm van eksegese ontwikkel het. Hierdie siening werp nuwe lig op die ou vraag of die kerk die Nuwe Testament op dieselfde wyse kan gebruik as wat die skrywers van die Nuwe Testament die Ou Testament gebruik het.

\section{Introduction}

It has always been the task of exegesis to distinguish between that which pertains to the particular situation of the biblical authors and that which is of abiding significance. For example, Paul can claim to uphold the teaching of the Law, while declaring that "in Christ Jesus neither circumcision nor uncircumcision counts for anything" (Gal. 5:6).2 Though such a position may appear obvious to us (are they not simply Jewish customs?), it was far from obvious to the first-century Church (e.g. Gal. 2; Rom. 4; Acts 15). How Paul came to this conclusion is difficult to determine. It was clearly not passed down to him from the first disciples, as they themselves had difficulty accepting it (Acts 10:14). Perhaps it was given to him directly by revelation (Gal. 1:12) or was implicit in his commission to take the gospel to the Gentiles (Acts 9:15). What is clear is that Paul defends his practice by engaging in biblical exegesis. For example, he argues that the righteousness attributed to Abraham in Genesis 15:6 was not the result of Abraham's faithfulness (i.e. works) but an act of faith, that is, he trusted in God's promise. Paul makes this point in two ways. In Galatians 3:15-18, he points out that this declaration of righteousness happened 430 years before the Law was given and so cannot be dependent on it. In Romans 4:9-12, he simply notes that the promise was given to Abraham before he was circumcised and so cannot be a necessary requirement. On the other hand, James 2:21-24 shows that other Christians could use this same text of Scripture to make a different point, namely, that faith is only of value if it shows itself in faithfulness, that is good works.

In the same way, the post-apostolic Church had to discern what was of abiding significance in the emerging New Testament documents and what should remain particular to the situation of the apostles. For example, in 1 Corinthians 7, Paul urges Christians not to marry because the end is near; it would be better for them to focus on the Lord's work. 
But the Lord did not come immediately and Christians of a later period had to decide whether this was particular advice for the first-century Christians or whether Paul taught that celibacy is the higher calling. Indeed, eschatology (the doctrine of the last things) is one of the most significant factors in biblical interpretation. Should we follow the practices of the first century and act as though the end was imminent? Or should we build churches, translate the Scriptures into every language and generally plan for the next generation? Indeed, it was only because the second- and third-century Church adopted the latter view that we have a New Testament at all.

All this raises many interesting questions but in this article, I wish to focus on just one of them. As we attempt to explain the meaning of the Bible to our students and congregations, can we use the same exegetical methods that the New Testament authors used, or do they belong to the particulars of the first century? The question is not a new one. Paul's allegory of the Sarah and Hagar story (Gal. 4) and some of Jesus' parables, such as the Sower (Mark 4) and the Vineyard (Mark 12) were the catalyst for the wholesale use of allegory in the Patristic and Medieval Church (Simonetti, 1994:34-52). This was challenged by the so-called Antiochene school (e.g. Diodore, Chrysostom) but it was the Reformers who were most successful in limiting allegorical interpretation to that which has a clear precedent in the Bible itself. 3 Nevertheless, the point remains: If Jesus and Paul both used allegory to discern the meaning of texts, why should we as contemporary preachers and scholars regard it as invalid? After all, Jesus said that his disciples should strive to be like their master (Matt. 10:25) and Paul told the Philippians (3:17) to be his imitators. Why should we exclude our use of Scripture from such imitation?

\section{Jewish exegesis in the first century}

The question about the use of the Old Testament has gained new momentum in the last fifty years with the discovery of the Dead Sea Scrolls. The Qumran community was a community that also believed that it had been raised by God in the last days and that its history (its origins in Damascus, the move to Qumran) and its personnel ("The Teacher of Righteousness" and his antagonist, "The Wicked Priest") were all

3 Recent works have rightly challenged the use of terms like "allegorical" and "literal" as heuristic descriptors of whole traditions such as Alexandrian and Antiochene exegesis (see Young, 1997) or Medieval and Reformation exegesis (see the articles in Muller \& Thomson, 1996). They are certainly important emphases in these traditions but disguise the fact that, for example, the Reformers do use allegory and the Alexandrians do speak of the literal sense of a text. On Calvin's interpretation of Scripture, see Puckett (1995). 
predicted in Scripture. According to Stegemann (1998:122), this view represented a departure from scribal exegesis (applying the Law to new situations) and the emergence of a new way of understanding Scripture:

A special insight on the part of the Teacher of Righteousness consisted in the concept that nothing that God had once had the biblical prophets commit to writing had ever referred to situations of those prophet's own time. From the outset, all of it had been God's solemn pronouncements for the last phase of history - precisely that time, then, in which the Teacher of Righteousness was living.

Not all would agree that the Teacher of Righteousness thought the prophets had nothing to say to their own generation but it is clear that the Qumran community believed they were living in the age of fulfilment. And that is why the Scriptures could be directly applied to their own people, events and circumstances. Similarly, the New Testament community believed they were living in the last days (Acts 2:17). According to Matthew, John the Baptist proclaimed, "Repent, for the kingdom of heaven has come near" (Matt. 3:3). According to Luke, Jesus announced that the prophecy of Isaiah 61 was being fulfilled that very day (Luke 4:21). Peter thought the Psalms spoke about the betrayal of Judas and the need to elect a successor (Acts 1:20). And Paul claimed that the Exodus story "was written down to instruct us, on whom the ends of the ages have come" (1 Cor. 10:11). Despite important differences, it is clear that both communities shared a similar eschatological outlook and scholars such as Ellis (1957), Lindars (1961) and Hanson (1983) have shown that they share many of the same exegetical techniques, of which the following are the most important.

\subsection{Typology}

Typology is seeing correspondences between people and events of the past and people and events of the present (or recent past). 4 In Romans 5:14, Paul says that Adam is a "type of the one to come" and uses this to clarify the work of Christ. In other passages, the actual word t úp o " is not used but it is clear that we are dealing with typology rather than prophecy and fulfilment since the original texts do not contain predictions (i.e. future verbs). Thus eating and drinking in the wilderness (1 Cor. 10) correspond to participation in the Christian Eucharist (both bring "types" of life). The lifting up of the serpent (John 3) corresponds to the

$4 \quad$ The standard works are Daniélou (1958), Lampe and Woollcombe (1957) and Goppelt (1982) but see Young (1997:161-213) for a recent challenge to the commonly held division between typology (acceptable) and allegory (unacceptable). According to Lindbeck (1999:29), "the main device for unifying the story of Jesus with the Old Testament tales of Israel was typological interpretation". 
crucifixion (both bring "types" of healing). And the waters of the flood (1 Pet. 3) corresponds to Christian baptism (both bring "types" of deliverance).

\subsection{Allegory}

Allegory has been variously defined but for the moment, we may simply say that it is the process whereby words and phrases are understood as possessing special (usually hidden) figurative or symbolic meanings in addition to their more usual sense.5 In Galatians 4, Paul allegorises the Sarah and Hagar story ("these women are two covenants") and in a seemingly audacious piece of exegesis, claims that Christians are the true descendants of Sarah ("the free woman"), whereas Jewish unbelievers ("the present Jerusalem") are descendants of Hagar ("the slave woman"). The parable of the Sower in Mark 4:3-9 is followed by an allegorical explanation in 4:14-20; the parable of the Vineyard in Mark 12:1-12 has obvious allegorical traits (mainly absent from the version in Gospel of Thomas: 65); and the book of Revelation offers a variety of symbolic interpretations (e.g. "the seven stars are the angels of the seven churches, and the seven lampstands are the seven churches" Rev. 1:20).

\subsection{Catch-word links}

Jewish exegesis was often facilitated by referring to other verses of Scripture which contain a similar theme or even a single word. We see the same technique in the New Testament. In Romans 4:1-12, Paul expounds the meaning of Genesis 15:6 ("the Lord reckoned it to him as righteousness") by referring to Psalm 32:1-2 ("blessed is the one against whom the Lord will not reckon sin"). Despite the fact that these texts come from different periods of Israel's history and belong to different genres of writing, the catch-word link (reckoned, reckon) allows Paul to equate God reckoning righteousness to Abraham with God not reckoning sin to David. Thus he deduces something that is not stated in Genesis 15 , namely that God's reckoning righteousness to Abraham implies that his sins are forgiven:

So also David speaks of the blessedness of those to whom God reckons righteousness irrespective of works: 'Blessed are those

$5 \quad$ Young (1997:191-2) suggests that "all reading of texts which involves entering the textworld, appropriating the perspective of the text, or reading ourselves into the text, is in some sense allegorical". She offers eight "types" of allegory (rhetorical, parabolic, prophetic, moral, psychological, philosophical, theological and figural) of which at least the prophetic, moral and figural overlap with traditional accounts of typology. See further Whitman $(1987,2000)$. 
whose iniquities are forgiven, and whose sins are covered ...' (Rom. 4:6-7).

Similarly, in Galatians 3, the "curse" of not obeying the Law (Deut. 27:26) has led Paul to another "curse" text, one which pronounces a curse on criminals left hanging on a tree (Deut. 21:23). Paul is able to use this connection by asserting that Christ's death on the cross/tree incurred the curse of Deuteronomy 21:23, which somehow (he does not explain how) removed the curse hanging over us as Law-breakers (Deut. 27:26).

\subsection{Structural forms of homiletic argumentation}

As well as using catch-word links, the New Testament appears to use a number of traditional structural forms of argumentation. For example, there is a form of debate known as yelammedenu (Bowker, 1977:96111), which begins with a question, cites relevant texts from the Law, illustrates the meaning of key terms with a story and closes by referring back to one of the key texts. Kimball (1994:119-135) makes a case for seeing this as underlying the parable of the Good Samaritan, which begins with a question ("What must I do to inherit eternal life?"), cites relevant texts (Deut. 6:5; Lev. 18:5; 19:18), illustrates the meaning of "neighbour" with a story ("the good Samaritan") and ends with a reference back to Leviticus 18:5 ("Go and do likewise"). The point of debate is of course the appropriateness or otherwise of the story. Had Jesus told a story where the man was feigning injury in order to ambush and rob him (a not uncommon experience in many modern cities), it would have led to a very different understanding of the legal texts (i.e. "neighbour" evidently does not include those who seek to rob you).

Carol Stockhausen (1993:143-164) argues that Paul's exegesis usually begins with a text (or event) from the Law, is explained by a reference to the prophets (or occasionally the wisdom writings) and uses pesher type exegesis (i.e. exegesis that resembles the Qumran pesherim or commentaries) to bring out its contemporary application. Again, the point of debate is whether the choice of prophetic text does in fact bring out the true meaning of the legal text or is an imposition (e.g. does Isa. 54:1 bring out the true meaning of the Sarah and Hagar story when quoted in Galatians 4:27 or does it simply say what Paul wants it to say?).

\subsection{Use of haggada legends}

In 1 Corinthians 10:4, as well as the innovative claim that the rock which supplied the wilderness generation with water was none other than Jesus Christ, Paul also claims that this rock used to accompany them on their journeys. Now one might conclude from this that Paul is making a 
christological deduction based on his belief in the pre-existence of Christ. But we hear a similar idea in a Jewish haggada legend, which says (text in Holmgren, 1999:32):

And so the well which was with the Israelites in the wilderness was a rock, the size of a large round vessel, surging and gurgling upward, as from the mouth of this little flask, rising with them up onto the mountains, and going down with them into the valleys. Wherever the Israelites would encamp, it made camp with them.

The written form of this legend (Sukkah 3.11) dates from about $400 \mathrm{CE}$ but it was hardly borrowed from Paul's letter to the Corinthians. In all probability, both Paul and the author/editor of Sukkah 3.11 are drawing on an ancient haggadah legend, which they appear to take as authoritative.

Twice in the New Testament (Gal. 3:19; Acts 7.53) we hear of the tradition that Moses received the Law on Mount Sinai through the mediation of angels. This is not found in the Hebrew text of Exodus but Josephus has Herod say, "we have learned from God the most excellent of our doctrines, and the most holy part of our law by angels sent by God" (Antiquities, 15:136. Trans. Whiston, 1995). It was perhaps suggested by the Greek rendering of Deuteronomy 33:2 ("the Lord has come from Sinai ... and on his right hand his angels with him").

Jude and 2 Peter both make use of legendary interpretations of Genesis 6 , which took "sons of God" to mean fallen angels, thus explaining the origin of a race of giants (see 1 Enoch 6-19). Jude also uses the tradition that after Moses had died, the archangel Michael disputed with Satan concerning the destination of his body. This legend is found in the apocryphal Assumption of Moses and relates to whether Moses is worthy of a place in the world to come because he murdered an Egyptian. Can we quote from such sources in the same way?

\subsection{Exploiting ambiguities in the text}

In Matthew 21:5 and John 19:24, the Hebrew parallelism of the quotations is deliberately ignored and the two lines are referred to two quite different objects or actions. In the first, Matthew quotes Zechariah 9:9 ("mounted on a donkey, and on a colt, the foal of a donkey") as fulfilled when the disciples bring Jesus a "donkey and a colt, and put their cloaks on them, and he sat on them". John takes Psalm 22:18 ("they divide my clothes among themselves, and for my clothing they cast lots") to make a distinction between sharing the outer garments and casting lots for the tunic. In both cases, the Hebrew parallelism is most naturally taken as referring to the same thing, not two different objects or actions. A 
possible explanation is that both authors are quoting from a Greek text rather than directly from a Hebrew text but even so, it is almost impossible to believe that they were ignorant of the most basic tenet of Hebrew poetry. It is much more likely that they thought the parallelism was providential and hence open to such uses.

\subsection{Quoting from variant texts}

This is somewhat different from Qumran or the Rabbis in that the New Testament authors generally quote from a Greek translation rather than from a Hebrew text.6.6 Thus, in one sense, they are always quoting from a variant text. But of particular interest are those occasions where they seem to have quoted a Greek text that diverges significantly from the Hebrew text that has come down to us. In Acts 15:16-17, a text of Amos 9:12 is quoted which apparently had the word "Adam" instead of "Edom". In this form, it is a promise that God will restore humanity (adam), whereas Hebrew manuscripts refer to the restoration for Edom. The author of Hebrews (10:5-7) obtains a proof-text for the incarnation by means of a Greek translation of Psalm 40:6, which read, "but a body you have prepared for me". Hebrew manuscripts do not speak of a "prepared body" but have the obscure expression, "ears you have dug for me" (NRSV footnote). Bruce (1964:232-3) argues that the Greek translator must have taken the Hebrew totum pro parte, that is, the digging out of the ears stands for the fashioning of a human body and so makes a similar point. However, it is surely doubtful that anyone reading a Hebrew text of Psalm 40:6 (prior to Christ) could possibly have concluded that it contains a prediction of the incarnation.

\subsection{Altering the quoted text}

In Matthew's quotation of Micah 5:2, he (or someone before him) has

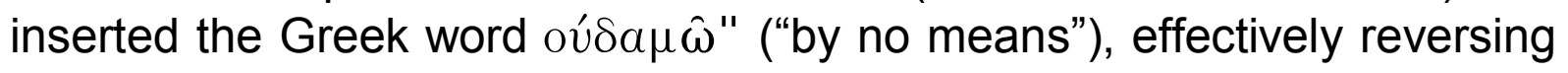
its meaning. According to Matthew, Bethlehem is "by no means least among the rulers of Judah", whereas the original quotation makes the opposite point. It would appear that Matthew wishes to assert that now that Jesus has been born in Bethlehem, it will no longer be considered insignificant. However, rather than spelling this out, he makes the point by simply modifying the wording of the quotation.

6 I use the indefinite article here to remind readers that the Greek and Hebrew texts were not "versions" like our modern translations of the Bible, where the text has been standardised. Thus Menken (1996) offers convincing evidence that some of the New Testament authors made use of Greek texts that had already undergone revision to bring them closer to the (known) Hebrew text. For an introduction to such issues and the use of the Old Testament in each of the New Testament books, see Moyise (2001). 
In John 13:8, the quotation used to support the betrayal of Judas (Ps. 41:9), differs from all known versions of the text. Menken (1990:6179) thinks that John has been influenced by another "betrayal" text, namely 2 Samuel 18:28, where Ahithophel betrays David and then hangs himself (2 Sam. 17:23). According to Menken, John has altered the text of Psalm 41:9 to avoid the implication that Jesus was betrayed $\pi \tau \epsilon \rho \nu \_\mu$ ó $($ ("by cunning"), a view clearly incompatible with the author's high christology.

\section{Analysis}

What are we to make of this? Can we use these very same techniques today to preach to our congregations and instruct our students? Hanson (1983:178-195) thinks not, arguing that the rise of historical criticism prohibits us from equating New Testament interpretations with what the original authors had in mind. Psalm 40:6 is not a prediction of the incarnation and Psalm 22:18 does not refer to a separate "casting of lots" for Jesus' tunic. Certainly we can learn from how they interpreted Scripture in their day but we "are not under any obligation to accept any given instance of a New Testament interpretation of the Old Testament just because it is in the New Testament" (Hanson, 1983:190). We no longer hold the same presuppositions as they did.

Longenecker (1994:385) agrees that we cannot emulate the more "bizarre" types of exegesis but maintains that we should nevertheless accept the validity of what we find in the New Testament:

We can appreciate something of how appropriate such methods were for the conveyance of the gospel then and of what was involved in their exegetical procedures. And we can learn from their exegetical methods how to contextualize that same gospel in our own day. But let us admit that we cannot possibly reproduce the revelatory stance of pesher interpretation, nor the atomistic manipulations of midrash, nor the circumstantial or ad hominem thrusts of a particular polemic of that day - nor should we try.

Longenecker claims that divine inspiration kept the apostles from committing actual error, despite the fact that many of their methods, especially using variant texts, haggada legends and various forms of text-manipulation, can hardly be regarded as legitimate today. Since we cannot claim such divine inspiration for our own interpretations, it is safer to limit our exegesis to modern historical, philological and grammatical analysis. We can repeat their answers (e.g. Psalm 22:18 is a reference to Jesus' tunic and the rock which followed the Israelites was Christ) because they were produced under divine inspiration. We should not, 
however, use these exegetical practices ourselves as part of our own exegesis of Scripture.

Such a response is understandable given the flights of fancy of many commentators (ancient and modern) but it comes at a high price. The implication is that the New Testament is an ancient text, no doubt recording valuable solutions to first-century problems, but certainly not a "living text" that speaks to each new generation. It implies that we should remain silent about modern issues such as AIDS, abortion or nuclear weapons simply because they were not envisaged by the biblical writers. But the whole purpose of biblical interpretation is to show how the ancient text does speak to new situations. If we relinquish that, we consign the Bible to the museum. As Young (1997:3) says, "Without a form of allegory that at least allows for analogy, the biblical text can only be an object of archaeological interest." Fortunately, more recent studies on the use of the Old Testament in the New Testament have taken a different approach and may offer a way out of this impasse.

\subsection{Donald Juel}

Juel argues for what he calls "messianic" or "christological" exegesis. He acknowledges that the New Testament authors were indebted to Jewish forms of exegesis but he does not think this gets to the heart of the matter: "The greatest difference between early Christian exegesis and other forms of Jewish scriptural interpretation is the impact made by Jesus" (Juel, 1988:57). The early Church viewed the Old Testament through the lens of Christ, who is not a rule or principle but the crucified and resurrected Messiah. Juel does not pursue the question of whether such hermeneutics should be normative for today's Church but he does end with the comment, "For NT Christianity, as for Paul, the good news was inextricably bound to the historical form in which God's grace was now to be encountered" (Juel, 1988:179). How this differs from other ways of reading (i.e. through different presuppositional lenses) is that "Christian interpretation of the Scriptures arose from the recognition that Jesus was the expected Messiah and that he did not fit the picture" (Juel, 1988:26). In other words, New Testament exegesis embodies both continuity and discontinuity. It is not simply a question of applying generally accepted techniques to show that Christ fulfils the Old Testament. There are examples of this (see above) but it is not the whole story. At the heart of Christian exegesis is not a rule or principle but a person. Furthermore, it is a person with a particular history, especially his death and resurrection. This certainly means understanding the Old Testament as predicting the life, death and resurrection of Christ (Luke 24:27). But on a more profound level, it means seeing a person as the key to interpretation rather than a principle or set of principles. 


\subsection{Richard Hays}

Richard Hays made an important contribution in his Echoes of Scripture in the Letters of Paul (1989). Hays suggests that Paul's exegesis is more accurately described as "ecclesiocentric" than "christocentric" (or christological). Unlike Matthew, very few of Paul's quotations are directly applied to Christ. The majority are applied to the Church and "God's purpose to raise up a worldwide community of people who confess his sovereignty and manifest his justice" (Hays, 1989:177). In his account of Paul's hermeneutics in 2 Corinthians 3 , Hays suggests that Paul's prime criterion for biblical interpretation is what it produces in the readers or hearers. Thus Paul begins a difficult and somewhat convoluted exegesis of Exodus 34 by saying:

You yourselves are our letter, written on our hearts, to be known and read by all; and you show that you are a letter of Christ, prepared by us, written not with ink but with the Spirit of the living God, not on tablets of stone but on tablets of human hearts (2 Cor. 3:2-3).

As far as Paul is concerned, the validity of his exegesis is not that he followed the commonly accepted practices of the day. Neither is it the fact that he viewed the story through a particular "christological" lens. Both of these are to some extent true but the criterion that matters to Paul is the fact that such exegesis produced a Christian community. The Corinthians, of all people, should not doubt Paul's interpretations because they evidently had the power to bring about Christ-like transformation. Thus for Paul, Jewish exegesis is not wrong because it fails to do justice to historical, grammatical or philological correctness. It is wrong because it does not produce the Christ-like transformation that is the goal of Paul's ministry. This only comes about when the veil is removed and that

all of us, with unveiled faces, seeing the glory of the Lord as though reflected in a mirror, are being transformed into the same image from one degree of glory to another; for this comes from the Lord, the Spirit (2 Cor. 3:18).

The point is that Hays does not regard Jewish exegesis or christological presuppositions as determining Paul's exegesis. Yes, Paul does look at the scriptures through a christological lens and yes, his methods can be paralleled in contemporary Jewish exegesis. But if Paul were asked to justify his interpretations, his answer would not be to quote exegetical rules, nor even to cite his christological presuppositions, but to point to living communities who are a "letter of Christ, prepared by us, written not with ink but with the Spirit of the living God, not on tables of stone but on tablets of human hearts" (2 Cor. 3:3). Thus according to Hays (1989: 
161), Paul "seems to have leaped - in moments of metaphorical insight to intuitive apprehensions of the meanings of texts without the aid or encumbrance of systematic reflection about his own hermeneutics". ?

Hays understands Longenecker's concern that this could lead to all sorts of fanciful exegesis but believes the risk must be taken. As Dodd (1952:127) pointed out long ago, the substructure of New Testament theology lies in its patterns of biblical interpretation. If modern historical study declares that invalid, it is hard to see how we can go on respecting its conclusions. As Hays says (1989:182), "Scriptural interpretation is the theological matrix within which the kerygma took shape; removed from that matrix, it will die". Longenecker's concern to regulate biblical interpretation is understandable but is founded on the mistaken view that validity implies universality. The Church cannot reproduce the exegesis of the New Testament in the sense of abstracting 7-8 exegetical principles and freely applying them to a host of other texts. Because Paul allegorised the story of Sarah and Hagar as part of a response to the problems in first-century Galatia, it does not mean that he would countenance the allegory of other "wife and maid" stories in the Bible or even that his own allegory would be appropriate in a different situation. As Hays says (1989:183):

Paul's readings of Scripture enact a certain imaginative vision of the relation between Scripture and God's eschatological activity in the present time. To learn from Paul how to read Scripture is to learn how to share that vision, so that we can continue to read and speak under the guidance of the Spirit, interpreting Scripture in light of the gospel and the gospel in light of Scripture.

What does this involve? Hays (1989:184-7) elaborates his proposal with five propositions:

- We should read Scripture as a narrative of election and promise.

- We should read it ecclesiocentrically. The meaning of Scripture is only disclosed to "communities that embody the obedience of faith".

7 Young (1997:29-45) says a similar thing about Patristic exegesis. Even the Antiochenes were aware that they had to go behind the words of Scripture to find the dianoia ("mind") but they could not always demonstrate the superiority of their exegesis on formal grounds alone. In such cases, they appealed to the "rule of faith" and assumed that their opponent's interpretations naturally lead to blasphemy and wickedness: "The 'Canon of Truth' or 'Rule of Faith' expresses the mind of scripture, and an exegesis that damages the coherence of that plot ... cannot be right" (Young, 1997:43). 
- We should read it in the service of proclamation. Meaning is produced at the interface of worldly engagement, not in some objective academic disengagement.

- We should read it as participants in the eschatological drama of redemption.

- We should read it in the light of the metaphorical nature of all interpretation. This will "prevent us from literalizing or absolutizing Paul's reading" and give us humility in offering our own.

Despite our yearning to know whether a particular interpretation is true or not, the answer is not found in the assurance that we used 'sound' exegetical methods. Nor is it found in our christological presuppositions, as if agreeing with Nicea and Chalcedon is enough to guarantee exegetical infallibility. These things are important but the ultimate test of a particular interpretation is whether it produces the sort of Christ-like transformation that was the goal of Paul's ministry. Of course, the difficulty with such a proposal is the following: How does one decide what constitutes Christ-like transformation? Holiness and obedience in one Church tradition can be regarded as superstition and subservience in another. Nevertheless, it would seem that Hays has put his finger on a key element of New Testament exegesis.

\subsection{Kevin Vanhoozer}

Our theme has also been taken up by systematic theologians. In good preaching alliteration, Vanhoozer (1998:431) suggests that the task of biblical interpretation should involve:

- faithfulness, that is, interpretations that extend the meaning of the text into new situations;

- fruitfulness, that is, interpretations that enliven the reader and show forth the Spirit's fruits;

- forcefulness, that is, interpretations that edify the community, resolve problems, foster unity etc;

- fittingness, that is, interpretations that embody the righteousness of God and contextualize Christ.

The term that best summarises these concerns is trinitarian interpretation. It involves the stability of the Father's creation (interpretations should extend the meaning of texts but not fundamentally alter them), the incarnation (interpretations should make Christ present) and the Spirit (interpretations should edify the community and show forth the Spirit's fruits). Vanhoozer agrees with Hays that the effects of a particular 
interpretation are one factor in determining its validity but he also wishes to stress the right of the original author to be properly understood. At times, this sounds like the modernist obsession with "original authorial intention" which, according to Hanson (1983:185), was not a major concern for the New Testament authors. However, Vanhoozer (1998: 413) goes on to say that this "original authorial intention" is not to be equated with the conscious thoughts of the biblical authors but concerns the written embodiment of their words in Scripture. In other words, it is the canonical meaning that the words have (and were destined to have) when they take their appropriate place in the canon of Scripture. We should thus read the Bible as the "Word of God", the content of which is Christ, and the instrument for such a reading is the Holy Spirit, for:

- The Spirit convinces us that the Bible is indeed divine as well as human (communication) and is thus to be read as a unified text.

- The Spirit illumines the letter by impressing its illocutionary (intended effect) on the reader.

- The Spirit's illumination of our minds is therefore dependent on his prior transformation of our hearts. Sanctification is thus the final aspect of the Spirit's work in interpretation.

Thus Vanhoozer attempts to integrate a spiritual reading strategy with the view that texts embody communication between authors and readers and can be elucidated by the application of ordinary linguistic tools. However, as I have written elsewhere (Moyise, 2002:3-21), I do not think Vanhoozer has sufficiently integrated his canonical understanding of Scripture (i.e. that God is the author) with his discussion of discerning original authorial intention. The tools used by modern critical scholars to discern what Isaiah or Ezekiel intended by a particular utterance are very different from what is needed to discern the divine meaning (dianoia) of a passage in its full canonical context. Vanhoozer devotes a great deal of time to broadening the definition of original authorial intention to include the latter but in my view, this simply confuses the issue. The contemporary quest for original authorial intention deliberately sets aside later Christian interpretations to discover what Ezekiel or Isaiah meant in their own day. As such, it is quite different to what the New Testament authors did. Nevertheless, Vanhoozer's work is an interesting attempt to integrate what is often called pre-critical and critical biblical interpretation.8 uncritical. The point is more that pre-Enlightenment exegesis was critical in a different way than post-Enlightenment exegesis (notably the latter's obsession with 


\section{Conclusion}

Can we use the New Testament the way the New Testament authors used the Old Testament? At the end of section 2, it looked like the answer to this question was going to be a definite no. It is simply not possible to abstract 7-8 exegetical techniques from the New Testament, apply them to other texts, and expect truth to be guaranteed. We are suspicious of allegory, scornful of text-manipulation and aware of the arbitrary (indeed ideological) nature of using cross-references to elucidate meaning. On the other hand, the writers discussed in section 3 all suggest that the heart of New Testament exegesis is not a matter of technique but the presence of the living God. Juel suggests that the key to New Testament exegesis is that the authors viewed the ancient scriptures through the lens of the crucified and risen Christ. Modern Christian interpreters can presumably do likewise. Hays, in an almost postmodern sense, argues that the main criterion for judging exegesis is the transforming effect it has (or does not have) on the Christian community. This raises a number of difficult questions in a divided Church but perhaps no more than in Paul's time. One might even suggest that something like this operates in the academic community, where only the passage of time decides whether a particular interpretation becomes a consensus. And Vanhoozer attempts a comprehensive account of biblical hermeneutics that seeks to unite original meaning, extended meaning and productive meaning.

Nevertheless, despite the inspirational nature of many of these suggestions, the exegete is still faced with the question of whether any or all of the techniques listed in section 2 will accomplish these various ends today. In other words, can a particular mode of theological interpretation (be it christological, ecclesiocentric or trinitarian) still make use of firstcentury forms of persuasion/rhetoric, such as allegory, cross-referencing and various forms of text-manipulation? Or should we consign them to the particulars of the first-century and seek to fulfil the vision of New Testament interpretation by using contemporary forms of persuasion? The two options may be spelt out thus:

\subsection{A theological hemeneutic that is still able to use first-century methods of persuasion}

This seems to be the view of Hays, who strongly challenges the idea that only those methods deemed acceptable by modern historical criticism and grammatical analysis are to be allowed. Why should 19th century

reconstructing the history behind the text). See further Muller and Thomson (1996:335345). 
rationalist hermeneutics be allowed to stand in judgement over the apostolic writings? Thus (Hays, 1989:187) states:

While we will continue to recognize Paul's readings of Scripture as abidingly valid figurations, we will also create new figurations out of the texts that Paul read, and we will do so in part by weaving Paul's own writings into the intertextual web, perhaps discerning correspondences that did not occur to Paul himself.

Notice how the postmodern literary concept of intertextuality (see Moyise, 2000:14-41) has replaced the Jewish techniques of catch-word links and illustrating stories. Associating texts with other texts and seeing multiple meanings in words and phrases is not simply a Christian technique. It is a property of all texts, which do not exist in isolation but only as part of a web or matrix of interlocking semiotic systems. What the New Testament authors did with the Old Testament is but a particular example of this.

Similarly, Young has argued that the abuses of allegory by certain Church Fathers should not lead us to reject it out of hand but to produce better and more authentic forms of allegory. We are now learning how impoverished our understanding of the parables has become under the influence of anti-allegorical dogma. To tell stories which include kings, shepherds and beloved sons as characters and seeds, vines and leaven as objects, was bound to generate figurative interpretations. And as for using variant texts, is this not what every scholar or preacher does when they quote from modern versions of the Bible? Even quoting from the latest Greek edition is to quote from a particular reconstruction of the text. The key criterion for interpretation is the fruit that it produces and any of the techniques discussed in section 2 could be the vehicle for such a transformation.

\subsection{An incamational hermeneutic that uses modem rather than ancient forms of persua sion}

A trinitarian mode of interpretation will naturally be incarnational and so adopt those forms of persuasion and argument that operate in any particular age or culture. We know from the Dead Sea Scrolls (see above) and interpreters like Philo (Cohen, 1995) that allegory, textmanipulation and the free association of texts were persuasive forms of argumentation in the first century. But they are not today, at least in those parts of the world that have been influenced by the Enlightenment. Here, it is scientific evidence, rational argument and historical objectivity that are highly prized. If Jesus is still to be regarded as the incarnation of God and born of the virgin Mary, it will not be because Isaiah 7:14 and 
Psalm 40:6 say so. Historical criticism has convincingly shown that Isaiah had a contemporary in mind (see Isa. 7:16) and linguistic analysis shows that "prepared body" is a mistranslation of the Hebrew of Psalm 40:6. To claim otherwise will simply alienate people of today and serve to discredit the gospel.

Thus just as Paul's task was to interpret the Jewish scriptures to his predominantly Gentile congregations, our task is to interpret the New Testament (and Old Testament) to our predominantly post-Enlightenment generation. This means, for example, viewing Jesus as a firstcentury Jew rather than the first Christian. It means setting Paul's teaching on women in the context of first-century patriarchal culture. It means acknowledging that the ending of Mark's Gospel (16:9-20) and the story of the woman taken in adultery (John 7:53-8:11) are not part of the original Gospels. Of course, such historical reconstructions are not to be regarded as "fact". They are always open to revision but the essential point is that they will only be replaced when better historical evidence becomes available or a less-biased application of the method is offered. We can no more return to pre-critical exegesis than Paul could return to Pharisaic interpretation. A trinitarian interpretation will not abandon the past but neither will it live in the past.

\section{Bibliography}

BOWKER, J.W. 1977. Speeches in Acts: A study in proem and yelammedenu form. New Testament Studies, 14:96-111.

BRUCE, F.F. 1964. The Epistle to the Hebrews. London : Marshal, Morgan \& Scott.

COHEN, N.G. 1995. Philo Judaeus: His universe of discourse. Frankfurt : Lang.

DANIÉLOU, J. 1958. The lord of history. London : Longmans.

DODD, C.H. 1952. According to the scriptures. The sub-structure of New Testament theology. London : Nisbet.

ELLIS, E. 1957. Paul's use of the Old Testament. Edinburgh : Clark.

GOPPELT, L. 1982. Typos: The typological interpretation of the Old Testament in the New. Grand Rapids : Eerdmans.

HANSON, A.T. 1983. The living utterances of God. London : Darton, Longman \& Todd.

HAYS, R.B. 1989. Echoes of scripture in the letters of Paul. New Haven : Yale University Press.

HOLMGREN, F.C. 1999. The Old Testament and the significance of Jesus. Grand Rapids : Eerdmans.

JUEL, D. 1988. Messianic exegesis. Christological interpretations of the Old Testament in early Christianity. Philadelphia : Fortress Press.

KIMBALL, C.A. 1994. Jesus' exposition of the Old Testament in Luke's Gospel. Sheffield : JSOT.

LAMPE, G.W.H. \& WOOLLCOMBE, K.J., 1957. Essays in typology. London : SCM.

LINDARS, B. 1961. New Testament apologetic. London : SCM.

LINDBECK, G.A. 1999. Postcritical canonical interpretation: Three modes of retrieval. (In Seitz, C. \& Green-McCreight, K., eds. Theological exegesis. Essays in honor of Brevard S. Childs. Grand Rapids : Eerdmans. p. 26-51.) 
LONGENECKER, R.N. 1994. 'Who is the prophet talking about?' Some reflections on the New Testament's use of the Old. (In Beale, G.K., ed. The right doctrine from the wrong texts. Grand Rapids : Baker books. p. 375-386.)

MENKEN, M.J.J. 1996. Old Testament quotations in the fourth Gospel: Studies in textual form. Kampen : Kok.

MENKEN, M.J.J. 1990. The translation of Psalm 41.10 in John 13.18. Journal for the Study of the New Testament, 40:61-79.

MOYISE, S. 2000. Intertextuality and the study of the Old Testament in the New. (In Moyise, S., ed. The Old Testament in the New. Essays in honour of J.L.North. Sheffield: Sheffield Academic Press. p. 14-41.)

MOYISE, S. 2001. The Old Testament in the New. London/New York : Continuum.

MOYISE, S. 2002. Does the author of Revelation misappropriate the scriptures? Andrews University Seminary Studies, 40(1):3-21.

MULLER, R.A. \& THOMSON, J.L., eds. 1996. Biblical interpretation in the era of the Reformation. Grand Rapids : Eerdmans.

PUCKETT, D.L. 1995. John Calvin's exegesis of the Old Testament. Louisville : Westminster John Knox Press.

SIMONETTI, M. 1994. Biblical interpretation in the early Church. An historical introduction to patristic exegesis. Edinburgh : Clark.

STEGEMANN, H. 1998. The library of Qumran. Grand Rapids : Eerdmans.

STOCKHAUSEN, C.K. 1993. 2 Corinthians 3 and the principles of Pauline exegesis. (In Evans, C.A. \& Sanders, J.A., eds. Paul and the scriptures of Israel. Sheffield : Sheffield Academic Press. p. 143-164.)

VANHOOZER, K.J. 1998. Is there a meaning in this text? The Bible, the reader, and the morality of literary knowledge. Grand Rapids : Zondervan.

WHISTON, W., trans. 1995. The works of Josephus. Peabody : Hendricksen.

WHITMAN, J. 2000. Interpretation and allegory: antiquity to the modern period. Leiden : Brill.

WHITMAN, J. 1987. Allegory. The dynamics of an ancient and medieval technique. Oxford : Clarendon.

YOUNG, F. 1997. Biblical exegesis and the formation of Christian culture. Cambridge : Cambridge University Press.

\section{Key concepts:}

allegory

hermeneutics

Qumran

typology

\section{Kernbegrippe:}

allegorie

hermeneutiek

Qumran

tipologie 